\title{
Early Eocene birds from La Borie, southern France
}

Estelle Bourdon, Cecile Mourer-Chauviré, and Yves Laurent

Acta Palaeontologica Polonica 61 (1), 2016: 175-190 doi:http://dx.doi.org/10.4202/app.00083.2014

The early Eocene locality of La Borie is located in the village of Saint-Papoul, in southern France. These Eocene flu-vio-lacustrine clay deposits have yielded numerous vertebrate remains. Mammalian taxa found in the fossiliferous levels indicate an age near the reference level MP 8-9, which corresponds to the middle Ypresian, early Eocene. Here we provide a detailed description of the avian remains that were preliminarily reported in a recent study of the vertebrate fauna from La Borie. A maxilla, a quadrate, cervical vertebrae, a femur and two tibiotarsi are assigned to the giant ground bird Gastornis parisiensis (Gastornithidae). These new avian remains add to the fossil record of Gastornis, which is known from the late Paleocene to middle Eocene of Europe, early Eocene of Asia and early Eocene of North America. Gastornis parisiensis differs from the North American Gastornis giganteus in several features, including the more ventral position of the narial openings and the slender orbital process of quadrate. Two tibiotarsi and one tarsometatarsus are assigned to a new genus and species of Geranoididae, Galligeranoides boriensis gen. et sp. nov. So far, this family was known only from the early and middle Eocene of North America. The fossils from La Borie constitute the first record of the Geranoididae in Europe. We show that Gastornis coexisted with the Geranoididae in the early Eocene of both Europe (La Borie) and North America (Willwood Formation). The presence of Geranoididae and the large flightless bird Gastornis on either side of the present-day North Atlantic provides further evidence that a high-latitude land connection existed between Europe and North America in the early Eocene.

Key words: Aves, Geranoididae, Gastornis, Galligeranoides, palaeobiogeography, Ypresian, Eocene, France.

Estelle Bourdon [EBourdon@snm.ku.dk], The Natural History Museum of

Denmark, Section of Biosystematics, University of Copenhagen, Universitetsparken 15, DK-2100 Copenhagen, Denmark; Cécile Mourer-Chauviré [cecile.mourer@univ-lyon1.fr], Université Claude Bernard Lyon 1, Laboratoire de Géologie de Lyon, Terre, Planètes et Environnement, UMR 5276, 2 rue Dubois, F-69622 Villeurbanne Cedex, France; Yves Laurent [Yves.LAURENT@ mairie-toulouse.fr], Association Paléontologique du Sud-Ouest, 13 chemin des Telles, F-31360 Roquefort-sur-Garonne, France, and 
Muséum d'Histoire Naturelle de Toulouse, 35 allées Jules Guesde, F-31000 Toulouse, France.

This is an open-access article distributed under the terms of the Creative Commons Attribution License (for details please see creativecommons.org), which permits unrestricted use, distribution, and reproduction in any medium, provided the original author and source are credited.

For Full text $(1,073.0 \mathrm{kB})$ 